\title{
Effects of reducing dietary crude protein and metabolic energy in weaned piglets
}

\author{
J. H. Lee ${ }^{1}$, H. B. Kim ${ }^{2}$, W. Yun ${ }^{1}$, W. G. Kwak ${ }^{1}$, C. H. Lee ${ }^{1}$, H. J. Oh ${ }^{1}$, D. W. Kim ${ }^{4}$, M. H. Song ${ }^{3 \#} \&$ \\ J. H. Cho ${ }^{1 \#}$ \\ ${ }^{1}$ Division of Food and Animal Science, Chungbuk National University, \#52 Naesudong-ro, Heungdeok-gu, \\ Cheongju, Chungbuk, 361-763, Republic of Korea \\ ${ }^{2}$ Department of Animal Resources and Science, Dankook University, Cheonan, 330-714, Republic of Korea \\ ${ }^{3}$ Department of Animal Science and Biotechnology, Chungnam National University, Daejeon, 305-764, Republic of \\ Korea \\ ${ }^{4}$ Department of Swine Science, National Institute of Animal Science, Cheonan, 310-00, Republic of Korea
}

(Received 17 April 2017; Accepted 8 June 2017; First published online 17 July 2017)

Copyright resides with the authors in terms of the Creative Commons Attribution 4.0 South African License.

See: http://creativecommons.org/licenses/by/4.0/za

Condition of use: The user may copy, distribute, transmit and adapt the work, but must recognize the authors and the South African Journal of Animal Science.

\begin{abstract}
The objective of this experiment was to determine the effects of a pure reduction in the dietary crude protein (CP) and metabolic energy (ME) contents on growth performance, nutrient digestibility, blood profile, faecal microflora and odour gas emission in weaned pigs. A total of 80 weaned piglets ((Landrace $\times$ Yorkshire) $\times$ Duroc) with a mean initial bodyweight (BW) of $6.8 \pm 0.5 \mathrm{~kg}$ were randomly allotted to four treatments with four replicate pens of five piglets per pen (based on average BW) for 45 days. The dietary treatments consisted of i) CON: basal diet; ii) LME: reduction of $10 \%$ of ME in basal diet; iii) LCP: reduction of $10 \%$ of CP in basal diet; iv) MECP: reduction of $10 \%$ of CP and $10 \%$ of ME in basal diet. During the experimental period, average daily feed intake (ADFI) improved in piglets fed the LME and LCP diets, compared with those fed the CON diets. Average daily gain (ADG) and gain to feed $(G: F)$ ratio decreased in piglets fed LCP, LME, and MECP diet, when compared with those fed the CON diet. However, during the total experimental period, $A D G$ and $G: F$ ratio were not affected by dietary treatment. With regard to nutrient digestibility, apparent total track digestibility (ATTD) of CP was not affected by experimental diets. The concentration of blood urea nitrogen (BUN) in blood decreased more in piglets fed LME, LCP, and MECP than those fed the CON diet. The emissions of ammonia $\left(\mathrm{NH}_{3}\right)$, hydrogen sufide $\left(\mathrm{H}_{2} \mathrm{~S}\right)$, and volatile fatty acids (VFAs) were lower in piglets fed LME, LCP, and MECP diet than those fed the CON diet. In conclusion, these results indicate that reduction in dietary $\mathrm{CP}$ and ME content did not decrease growth performance and nutrient digestibility, and they increased positive effects such as BUN and gas emission reduction.
\end{abstract}

Keywords: Blood profile, digestibility, growth performance, odour emission, pig

*These authors contributed equally to this work

\# Corresponding author: mhsong@cnu.ac.kr, jinhcho@cbnu.ac.kr

\section{Introduction}

Dietary energy and protein are important for growth in pigs. Supplementation of fat and increasing nutrient concentration in diets has been reported to improve ADG and G : F ratio (Song et al., 2003; Hastad et al., 2005). Yan et al. (2010) found that growing-finishing pigs fed high energy density diets had greater $A D G$ and $G: F$ ratio, associated with improved feed intake and digestibility, than pigs fed low energy density diets. An increase in nutrient density, such as protein and energy, is expected to raise nutrient intake and weight gain. Additionally, dietary adjustment was aimed at maximizing production performance without regard to nutrient oversupply, namely protein and amino acids (Lee et al., 2001). However, several studies found that energy levels in the diets did not affect growth performance in weaned piglets (Tokach et al., 1995; Smith et al., 1999). Digestibility of CP at the terminal ileum was from $60 \%$ to $80 \%$ in weaning pigs fed a diet based on triticale and wheat (Hogberg \& Lindberg, 2004). That means there is much more protein and energy that cannot be digested in diets for piglets than expected. Undigested protein causes a rapid increase in pathogenic bacteria and diarrhoea through fermentation gas (VFA, ammonia, amine, indoles, phenols and branched-chain fatty acids) in the gastrointestinal tract (Dong et al., 1996; Bolduan et al., 1988; Aumaitre et al., 1995; Anderson et al., 1999; Gaskins, 2001; Pluske et al., 2002; Houdijk et al., 2007). The components of mixed ammonia, VFAs, alcohols and sulfides through fermentation in the intestine causes odour and environmental pollution (Burnett, 1969; Miner, 1977; Ritter 1989; Hartung \& Phillips, 1994; Zahn et al. 1997). 
Therefore, the current study was conducted to investigate the effects of reducing CP and ME levels in diet on growth performance, nutrient digestibility, blood profile, faecal microflora, and odour gas emission in weaned piglets.

\section{Materials and methods}

The experimental protocol used in this study was approved by the Animal Care and Use Committee of Chungbuk National University. A total of eighty weaned piglets ((Landrace $\times$ Yorkshire $) \times$ Duroc) with mean initial BW of $6.8 \pm 0.5 \mathrm{~kg}$ were used in 45 experimental days. These piglets were allotted to one of four experimental diets based on average BW at weaning in a complete block design and four replicates with five pigs per pen in each replication. Dietary treatments consisted of i) CON: basal diet; ii) LME: reduction of $10 \%$ of ME in basal diet; iii) LCP: reduction of $10 \%$ of CP in basal diet; iv) MECP: reduction of $10 \%$ of CP and $10 \%$ of ME in basal diet. The experiment included two phases: phase 1 provided the diet in days 0 to 14 and phase 2 provided with diet in days 15 to 42 . Ingredients and nutrient composition of basal diet are provided in Table 1. All diets for weaned piglets were formulated to meet or exceed the recommendations of NRC (1998). All pigs were allowed to consume feed and water ad libitum from a feeder and water nipple in an environmentally controlled nursery room. This room was provided with artificial light for 24 hours a day and maintained at a temperature between $27^{\circ} \mathrm{C}$ and $30^{\circ} \mathrm{C}$.

Table 1 Ingredient and nutrient composition of experimental diets fed to weaning pigs

\begin{tabular}{|c|c|c|c|c|c|c|c|c|}
\hline \multirow{2}{*}{ Items } & \multicolumn{4}{|c|}{ Phase 1 (days $0-14$ ) } & \multicolumn{4}{|c|}{ Phase 2 (days 15-42) } \\
\hline & CON & LME & LCP & MECP & CON & LME & LCP & MECP \\
\hline \multicolumn{9}{|l|}{ Ingredients, \% } \\
\hline Corn & 41.67 & 47.17 & 45.01 & 50.31 & 56.84 & 61.85 & 63.55 & 67.45 \\
\hline Soybean meal, $48 \%$ & 30.00 & 29.00 & 30.00 & 29.00 & 30.00 & 29.00 & 25.00 & 23.00 \\
\hline Lactose & 10.00 & 10.00 & 10.00 & 10.00 & 0.00 & 0.00 & 0.00 & 0.00 \\
\hline Wheat bran & 0.00 & 0.00 & 0.00 & 0.00 & 5.00 & 5.00 & 3.00 & 5.00 \\
\hline Whey dried & 5.00 & 5.00 & 5.00 & 5.00 & 0.00 & 0.00 & 0.00 & 0.00 \\
\hline Fish meal & 5.00 & 5.00 & 1.00 & 0.00 & 0.00 & 0.00 & 0.00 & 0.00 \\
\hline (Menhaden) & 5.00 & 1.00 & 5.00 & 1.00 & 5.00 & 1.00 & 5.00 & 1.00 \\
\hline Lard & 0.21 & 0.21 & 0.39 & 0.39 & 0.21 & 0.20 & 0.30 & 0.33 \\
\hline L-Lysine-HCl & 0.04 & 0.04 & 0.04 & 0.60 & 0.04 & 0.04 & 0.04 & 0.04 \\
\hline DL-Methionine & 0.03 & 0.03 & 0.11 & 0.15 & 0.03 & 0.03 & 0.03 & 0.10 \\
\hline L-Threonin & 1.00 & 1.00 & 1.40 & 1.50 & 1.00 & 1.00 & 1.20 & 1.20 \\
\hline Dicalcium phosphate & 1.25 & 1.25 & 1.25 & 1.25 & 1.25 & 1.25 & 1.25 & 1.25 \\
\hline Limestone & 0.50 & 0.00 & 0.50 & 0.50 & 0.50 & 0.50 & 0.50 & 0.50 \\
\hline Salt & 0.10 & 0.10 & 0.10 & 0.10 & 0.08 & 0.05 & 0.05 & 0.05 \\
\hline Vitamin premix ${ }^{3}$ & 0.20 & 0.20 & 0.20 & 0.20 & 0.05 & 0.08 & 0.08 & 0.08 \\
\hline \multicolumn{9}{|c|}{ Calculated composition, $\mathrm{g} / \mathrm{kg}$} \\
\hline $\mathrm{ME}, \mathrm{Kcal} / \mathrm{kg}$ & 3508 & 3344 & 3487 & 3283 & 3459 & 3289 & 3484 & 3277 \\
\hline Crude Protein & 217 & 217 & 197 & 196 & 200 & 199 & 179 & 177 \\
\hline Calcium & 10.8 & 10.8 & 9.6 & 9.3 & 8.0 & 7.9 & 8.2 & 8.2 \\
\hline Lys & 14.6 & 14.5 & 14.2 & 13.6 & 12.5 & 12.3 & 11.7 & 11.6 \\
\hline Met & 4.1 & 4.1 & 3.4 & 3.4 & 3.5 & 3.5 & 3.2 & 3.2 \\
\hline
\end{tabular}

CON: basal diet; LME: reduction of $10 \%$ of ME in basal diet; LCP: reduction of $10 \%$ of CP in basal diet; MECP: reduction of $10 \%$ of CP and $10 \%$ of ME in basal diet.

${ }^{1}$ Standard levels of metabolic energy and crude protein; ${ }^{2}$ Reducing metabolic energy and crude protein levels

${ }^{3}$ Provided per kilogram of diet: $4,500 \mathrm{mg}$ of vitamin A, $93.75 \mathrm{mg}$ of vitamin D3, $37.5 \mathrm{mg}$ of vitamin E, $2.55 \mathrm{mg}$ of vitamin $\mathrm{K} 3,3 \mathrm{mg}$ of thiamin, $7.5 \mathrm{mg}$ of riboflavin, $4.5 \mathrm{mg}$ of vitamin B6, $24 \mu \mathrm{g}$ of vitamin B12, $51 \mathrm{mg}$ of niacin, $1.5 \mathrm{mg}$ of folic acid, $0.2 \mathrm{mg}$ of biotin, and $13.5 \mathrm{mg}$ of pantothenic acid; $37.5 \mathrm{mg}$ of $\mathrm{Zn}, 37.5 \mathrm{mg}$ of $\mathrm{Mn}, 37.5 \mathrm{mg}$ of Fe, $3.75 \mathrm{mg}$ of $\mathrm{Cu}, 0.83 \mathrm{mg}$ of $\mathrm{I}, 62.5 \mathrm{mg}$ of $\mathrm{S}$, and $0.23 \mathrm{mg}$ of $\mathrm{Se}$ 
After the feed and faecal samples were mixed with a blender, they were analysed for dry matter (DM) (method 930.15) (AOAC, 2005) and CP (method 990.03) (AOAC, 2005) concentrations. Nitrogen (N) was determined with a Kjeltec 2300 nitrogen analyser (Foss Tecator AB, Hoeganaes Sweden). CP was calculated as $\mathrm{N} \times 6.25$. Gross energy (GE) was analysed by the heat of combustion in the sample with a Parr 6100 oxygen bomb calorimeter (Parr Instrument Co., Moline, IL).

During the experiment, individual BWs of piglets and feed consumption were weighed at days 0,14 , 42 of the experimental period and recorded to calculate $A D G, A D F I$ and $G: F$ ratio. All piglets were fed diets to which $0.20 \%$ chromic oxide $\left(\mathrm{Cr}_{2} \mathrm{O}_{3}\right)$ was added as an indigestible marker on day 38 to determine the ATTD of DM, CP and energy (Ball \& Aherne, 1987).

Faecal samples were collected from all piglets by rectal massage and stored at $-20{ }^{\circ} \mathrm{C}$ in the refrigerator. Additionally, frozen faecal samples were mixed in a blender for 15 minutes and then analysed with the above methods (AOAC, 2005). Chromium was determined via ultraviolet absorption spectrophotometry (UV-1201, Shimadzu, Kyoto, Japan), according to the method of Williams et al. (1962). The ATTD of DM and N were calculated with indirect-ratio methods using the following formula:

Coefficient of apparent total tract digestibility $=\{1-[(\mathrm{Nf} \times \mathrm{Cd}) /(\mathrm{Nd} \times \mathrm{Cf})]\} \times 100$

where: $\mathrm{Nf}=$ nutrient concentration in faeces $(\% \mathrm{DM})$

$\mathrm{Nd}=$ nutrient concentration in diet $(\% \mathrm{DM})$

$\mathrm{Cf}=$ chromium concentration in faeces $(\% \mathrm{DM})$

$\mathrm{Cd}=$ chromium concentration in diets (\% DM)

To measure the blood profile, all piglets from each pen were used to collect blood samples. These samples were collected via vacuum tubes (Becton Dickinson \& Co., Franklin Lakes, NJ) on day 41. They were transferred and pre-processed as described in Hossain et al. (2016). The concentration of red blood cells (RBC) and white blood cells (WBC) and lymphocyte percentage were analysed with an automatic blood analyser (ADVIA, Bayer, Tarrytown, NY). The concentration of immunoglobulin G (IgG) and BUN were determined with a nephelometer (Dade Behring, Marburg, Germany) and the concentrations of BUN and glucose were determined with an automatic biochemistry analyser (Hitachi 747, Hitachi Ltd., Tokyo, Japan).

To measure odour gas emission, faeces and urine were collected from all piglets of each pen at day 42 of the experimental period. Faecal and urine $(100 \mathrm{~g}+100 \mathrm{~g})$ samples were mixed and stored in a plastic box (Size: $4.2 \mathrm{~L}$ ) at room temperature $\left(28^{\circ} \mathrm{C}\right.$ ) and allowed to ferment from days 42 to 45 . The plastic boxes were punctured with a roasting drill and headspace air was sampled approximately $2.0 \mathrm{~cm}$ above the samples (faeces and urine) at a rate of $100 \mathrm{~mL} / \mathrm{min}$. The concentrations of $\mathrm{NH}_{3}, \mathrm{H}_{2} \mathrm{~S}$ and VFAs were measured using a gas detector tube of Gastec Corp (scope of 1.0-30.0 ppm; No. 3L for $\mathrm{NH}_{3}$, scope of 2.560.0 ppm; No. 4LL for $\mathrm{H}_{2} \mathrm{~S}$ and scope of $0.25-10.0 \mathrm{ppm}$; No. 81L for VFA).

After measuring odour gas emission, the rest of the faeces was used to analyse microbiota and stored until further analyses in the laboratory refrigerator. The dilution and counting for measuring microbiota in the faeces were carried out in the same way as Zhao et al. 2013 had recorded.

All the data concerning growth performance, nutrient digestibility, blood profile, odour gas emission and faecal microbiota were analysed by ANOVA using the general linear model (GLM) procedure of SAS (SAS Institute, 2008), with the pen being defined as the experimental unit. Differences among treatments were separated by Duncan's multiple range test. The results were expressed as the least square mean and SEM. Probability values less than 0.05 were considered significant.

\section{Results}

Growth performances of piglets fed experimental dietary treatments are presented in Table 2. The final BW of weaned piglets fed the CON diet was greater $(P<0.05)$ by $1.0 \mathrm{~kg}$ and by $0.64 \mathrm{~kg}$, respectively, compared with weaned piglets fed LCP and MECP diet. The ADFI decreased $(P<0.05)$ in piglets fed the CON diet for days 0 to 14 , compared with those fed the other treatment diets. During days 14 to 42 and for the whole experimental period, ADFI improved $(P<0.05)$ in piglets fed the LME and LCP diets compared with those fed the CON diets. ADG and $G: F$ ratio decreased $(P<0.05)$ in piglets fed the LCP, LME and MECP diets, compared with those fed the CON diet. However, during the total experimental period, ADG and $G: F$ ratio were not affected $(P>0.05)$ by dietary treatment. 
Table 2 Effects of low metabolic energy and crude protein in diets on growth performance in weaning pigs ${ }^{1}$

\begin{tabular}{|c|c|c|c|c|c|c|}
\hline Items $^{2}$ & CON & LME & LCP & MECP & $\mathrm{SE}^{3}$ & P-value \\
\hline \multicolumn{7}{|c|}{ Bodyweight, kg } \\
\hline d 0 & 6.83 & 6.81 & 6.78 & 6.79 & & \\
\hline d 14 & 15.05 & 15.02 & 15.12 & 15.14 & 0.13 & 0.90 \\
\hline d 42 & $28.30^{a}$ & $27.80^{\mathrm{ab}}$ & $27.30^{b}$ & $27.36^{b}$ & 0.28 & 0.04 \\
\hline \multicolumn{7}{|l|}{$\mathrm{ADG}, \mathrm{g}$} \\
\hline d 0-14 & 391.6 & 391.2 & 397.2 & 397.7 & 7.0 & 0.86 \\
\hline d 14-42 & $630.8^{a}$ & $608.3^{\mathrm{ab}}$ & $579.7^{b}$ & $581.9^{b}$ & 13.4 & 0.02 \\
\hline d 0-42 & 511.1 & 499.8 & 488.4 & 489.9 & 7.0 & 0.08 \\
\hline \multicolumn{7}{|l|}{ ADFI, $g$} \\
\hline d 0-14 & $621.0^{c}$ & $627.8^{\mathrm{ab}}$ & $626.0^{\mathrm{b}}$ & $631.5^{\mathrm{a}}$ & 1.8 & 0.01 \\
\hline d 14-42 & $865.8^{a}$ & $858.5^{b}$ & $860.3^{b}$ & $866.3^{a}$ & 1.2 & 0.01 \\
\hline d 0-42 & $687.5^{\mathrm{b}}$ & $686.5^{\mathrm{b}}$ & $686.0^{\mathrm{b}}$ & $691.0^{a}$ & 0.9 & 0.01 \\
\hline \multicolumn{7}{|l|}{$G: F$} \\
\hline d $0-14$ & 0.631 & 0.623 & 0.635 & 0.630 & 0.011 & 0.90 \\
\hline d 14-42 & $0.729^{a}$ & $0.709^{a b}$ & $0.674^{b}$ & $0.673^{b}$ & 0.015 & 0.03 \\
\hline d 0-42 & 0.744 & 0.729 & 0.712 & 0.709 & 0.010 & 0.07 \\
\hline
\end{tabular}

${ }^{\mathrm{CON}}$ : basal diet; LME: reduction of $10 \%$ of ME in basal diet; LCP: reduction of $10 \%$ of CP in basal diet; MECP: reduction of $10 \%$ of $\mathrm{CP}$ and $10 \%$ of $\mathrm{ME}$ in basal diet

${ }^{2}$ ADG: average daily gain; ADFI: average daily feed intake; $G$ : F: gain to feed ratio

${ }^{3}$ Standard error

${ }^{\mathrm{ab}}$ Means in the same row with different superscripts differ $(P<0.05)$

The ATTD of DM, CP and GE of piglets fed experimental dietary treatment are presented in Table 3. The ATTD of DM and GE decreased $(P<0.05)$ in piglets fed LME, LCP and MECP diets compared with those fed the CON diet. However, there were no significant differences $(P>0.05)$ in ATTD of CP among CON, LME and LCP treatments.

Table 3 Effects of low metabolic energy and crude protein in diets on nutrient digestibility in weaning pigs ${ }^{1}$

\begin{tabular}{lcccccc}
\hline Items, $\%$ & CON & LME & LCP & MECP & SE $^{2}$ & P-value \\
\hline Dry matter & $84.78^{\mathrm{a}}$ & $81.01^{\mathrm{c}}$ & $82.69^{\mathrm{b}}$ & $78.07^{\mathrm{d}}$ & 0.50 & 0.01 \\
Crude protein & $80.08^{\mathrm{a}}$ & $78.64^{\mathrm{ab}}$ & $76.90^{\mathrm{ab}}$ & $71.94^{\mathrm{b}}$ & 0.83 & 0.01 \\
Gross energy & $84.18^{\mathrm{a}}$ & $81.15^{\mathrm{b}}$ & $79.45^{\mathrm{b}}$ & $76.29^{\mathrm{c}}$ & 0.55 & 0.01
\end{tabular}

${ }^{T}$ CON: basal diet; LME: reduction of $10 \%$ of ME in basal diet; LCP: reduction of $10 \%$ of CP in basal diet; MECP: reduction of $10 \%$ of $\mathrm{CP}$ and $10 \%$ of $\mathrm{ME}$ in basal diet

${ }^{2}$ Standard error

${ }^{a b}$ Means in the same row with different superscripts differ $(P<0.05)$

Blood profiles of piglets fed the experimental dietary treatments are presented in Table 4. The concentrations of glucose, IgG, WBC, RBC and lymphocyte percentage were not affected $(P>0.05)$ by dietary treatment. However, the concentration of BUN decreased $(P<0.05)$ in piglets fed LME, LCP and MECP compared with those fed the CON diet.

Emissions of $\mathrm{NH}_{3}, \mathrm{H}_{2} \mathrm{~S}$ and VFAs of piglets fed the experimental dietary treatment are presented in Table 5. Odour emissions such as $\mathrm{H}_{2} \mathrm{~S}$ and VFAs of piglets fed LME, LCP and MECP diets and emission of $\mathrm{NH}_{3}$ of piglets fed LCP and MECP diet decreased $(P<0.05)$ compared with the CON diet. 
Table 4 Effects of low metabolic energy and crude protein in diets on blood profile in weaning pigs ${ }^{1}$

\begin{tabular}{lcccccc}
\hline Items $^{2}$ & CON & LME & LCP & MECP & SE $^{3}$ & P-value \\
\hline BUN, mg/dL & $10.4^{\mathrm{a}}$ & $7.5^{\mathrm{b}}$ & $6.2^{\mathrm{b}}$ & $7.8^{\mathrm{b}}$ & 0.8 & 0.01 \\
Glucose, $\mathrm{mg} / \mathrm{dL}$ & 104 & 105 & 103 & 102 & 10 & 0.10 \\
$\mathrm{lgG}, \mathrm{mg} / \mathrm{dL}$ & 228 & 240 & 216 & 220 & 17 & 0.70 \\
$\mathrm{WBC}, 10^{3} / \mu \ell$ & 20.0 & 19.1 & 19.4 & 16.8 & 1.6 & 0.51 \\
$\mathrm{RBC}, 10^{6} / \mu \ell$ & 7.00 & 6.26 & 6.81 & 6.84 & 0.22 & 0.13 \\
Lymphocyte, \% & 77.8 & 76.0 & 80.8 & 77.5 & 1.7 & 0.34
\end{tabular}

${ }^{1}$ CON: basal diet; LME: reduction of $10 \%$ of ME in basal diet; LCP: reduction of $10 \%$ of CP in basal diet; MECP: reduction of $10 \%$ of $\mathrm{CP}$ and $10 \%$ of $\mathrm{ME}$ in basal diet

${ }^{2} \mathrm{BUN}$ : blood urea nitrogen; IgG: immunoglobulin G; WBC: white blood cell; RBC: red blood cell

${ }^{3}$ Standard error

${ }^{\mathrm{ab}}$ Means in the same row with different superscripts differ $(P<0.05)$.

Table 5 Effects of low metabolic energy and crude protein in diets on odour gas emission in weaning pigs ${ }^{1}$

\begin{tabular}{lcccccc}
\hline Items, $\mathbf{p p m}^{\mathbf{2}}$ & CON & LME & LCP & MECP & SE $^{3}$ & P-value \\
\hline $\mathrm{NH}_{3}$ & $3.64^{\mathrm{a}}$ & $3.35^{\mathrm{a}}$ & $1.69^{\mathrm{b}}$ & $1.31^{\mathrm{b}}$ & 0.46 & 0.0001 \\
$\mathrm{H}_{2} \mathrm{~S}$ & $17.25^{\mathrm{a}}$ & $13.00^{\mathrm{b}}$ & $10.88^{\mathrm{b}}$ & $10.75^{\mathrm{b}}$ & 2.02 & 0.0004 \\
VFAs & $3.00^{\mathrm{a}}$ & $0.75^{\mathrm{b}}$ & $1.38^{\mathrm{b}}$ & $1.00^{\mathrm{b}}$ & 0.42 & $<.0001$
\end{tabular}

${ }^{1}$ CON: basal diet; LME: reduction of $10 \%$ of ME in basal diet; LCP: reduction of $10 \%$ of CP in basal diet; MECP: reduction of $10 \%$ of $\mathrm{CP}$ and $10 \%$ of $\mathrm{ME}$ in basal diet

${ }^{2} \mathrm{NH}_{3}$ : ammonia; $\mathrm{H}_{2} \mathrm{~S}$ : hydrogen sulfide; VFAs: volatile fatty acids

${ }^{3}$ Standard error

${ }^{\mathrm{ab}}$ Means in the same row with different superscripts differ $(P<0.05)$

Microbiota in faeces of piglets fed the experimental dietary treatments are presented in Table 6 . There were no significant differences $(P>0.05)$ between treatments in the faecal $E$. coli counts. However, Lactobacillus counts in piglets fed the LCP diet decreased $(P<0.05)$ compared with those fed other diets.

Table 6 Effects of low metabolic energy and crude protein in diets on faecal microbiota in weaning pigs ${ }^{1}$

\begin{tabular}{lcccccc}
\hline Items, log10/g & CON & LME & LCP & MECP & SE $^{2}$ & P-value \\
\hline Lactobacillus & $7.83^{\mathrm{a}}$ & $7.50^{\mathrm{ab}}$ & $7.31^{\mathrm{b}}$ & $7.54^{\mathrm{ab}}$ & 0.16 & 0.01 \\
E. coli & 5.07 & 4.67 & 5.20 & 4.50 & 0.34 & 0.55
\end{tabular}

${ }^{T}$ CON: basal diet; LME: reduction of $10 \%$ of ME in basal diet; LCP: reduction of $10 \%$ of CP in basal diet; MECP: reduction of $10 \%$ of $\mathrm{CP}$ and $10 \%$ of $\mathrm{ME}$ in basal diet

${ }^{2}$ Standard error

${ }^{\mathrm{ab}}$ Means in the same row with different superscripts differ $(P<0.05)$

\section{Discussion}

Previous studies in which reducing $4 \%$ dietary CP with supplementation of amino acid (AA) during the nursery phase have shown that growth performance could be maintained compared with a control diet formulated to meet or exceed NRC (1998) recommendations (Hansen et al., 1993; Kerr et al., 1995). Reducing dietary CP with supplementation of AA indicated positive effects such as a reduction in the amount 
of $\mathrm{N}$ excreted, improving or maintaining performance, and carcass composition against control diet (Wahlstrom \& Libal, 1974; Easter \& Baker, 1980; Kerr \& Easter, 1995; Kendall, 2000; Figueroa et al., 2002). However, previous studies did not conduct experiments but merely reduced CP in diets, and growth performance and carcass characteristics of pigs fed reduced CP diets varied (Dourmad et al., 1993; Kerr et al., 1995; Figueroa et al., 2002). Therefore, this experiment was performed to investigate the effects of pure reduction of $\mathrm{CP}$ and ME content in diets on growth performance, nutrient digestibility, blood profile, faecal microflora and odour gas emission in weaned piglets.

Supplementation of dietary protein and energy in the weaning phase is closely related to growth performance. Kephart \& Sherrit (1990) and Shriver et al. (2003) reported that pigs fed a low CP amino acidsupplemented diet had slower growth rates than those fed the CON diet. Additionally, Russell et al. (1983) reported that growth performance was not affected by reducing CP by $4 \%$ with the addition of lysine, tryptophan and threonine. In the current study, it was shown that pigs fed three treatment diets (LME, LCP, and MECP) decreased $(P<0.05)$ in $A D G$ and $G: F$ ratio compared with pigs that were fed control diet on days 14 to 42, although there were no significant differences $(P>0.05)$ between the $C O N$ and treatment diets on days 0 to 42. On days 0 to 14, pigs fed the three treatment diets increased in ADFI compared with those that were fed the control diet. However, there were no significant difference $(P>0.05)$ on days 14 to 42 and on days 0 to 42 between the CON, LME and LCP treatments. According to the results of growth performance, final bodyweight was significantly decreased by LCP, MECP diets at day 42 . However, since this is the result from a limited period, further research should be conducted from new-born to shipment.

In the current experiment, the results showed that pigs fed the control diet increased $(P<0.05)$ in digestibility of DM and GE compared with pigs fed the three treatment diets. Stahly (1984) reported that the supplementation of fat in diets increased nutrient digestibility. These results mean that fat is digested more efficiently, which promotes more energy being available, since less heat is being in fermentation and nutrient metabolism. Therefore, the digestibility of pig fed the control diet was higher than pigs fed the treatments. Bikker et al. (2006) reported that the apparent ileal digestibility (AID) of CP in weanling pigs was decreased by reducing the dietary CP content from $21.7 \%$ to $15.3 \%$ by replacing soybean meal in a high-CP diet with wheat in the low CP diet. Also, numerous reports indicated an increase in nitrogen digestibility as CP levels rose (Just, 1982a; Just, 1982b; Noblet et al., 1987; Kephart \& Sherritt, 1990). However, results of the digestibility of CP from the current study are different from those performed by Noblet et al. (1987), Kephart \& Sherritt. (1990) and Bikker et al. (2006). Our results showed that pigs fed LCP diet in the digestibility of CP was similar to pigs fed CON diet.

Results from the current experiment showed that BUN of pigs fed the control diet increased $(P<0.05)$ compared with pigs fed the treatment diets. However, there were no significant differences $(P>0.05)$ among the experimental diets on glucose, IgG, WBC, RBC and lymphocyte. Whittemore et al. (1978) and Whang et al. (2003) found that the BUN levels or N breakdown and excretion were lower in the pigs fed a proteindeficient diet than those that were fed a normal diet. For unknown reasons, results from the current experiment showed similar results to those reported by Whittemore et al. (1978) and Whang et al. (2003).

Compounds that cause odour may be classified in four groups: i) sulfurous compounds; ii) indolic and phenolic compounds; iii) VFAs; and iv) ammonia and amines (Bonnin et al., 1990). The production of microbial metabolites (ammonia and VFAs) in digesta were used as indicators of intestinal health and microbial activity (Nyachoti et al., 2006). In the current study, it was shown that $\mathrm{NH}_{3}, \mathrm{H}_{2} \mathrm{~S}$, VFAs emissions in pigs fed LCP and LME were lower $(P<0.05)$ than in pigs fed the control diet. Further, the odour emission $\left(\mathrm{H}_{2} \mathrm{~S}\right.$ and VFAs) of pigs fed the MECP diet was similar to pigs fed the LME and LCP diets. Reduced odour gases such as $\mathrm{NH}_{3}, \mathrm{H}_{2} \mathrm{~S}$, VFAs in weaned piglets fed low protein and low metabolic energy diets agrees with those reported by Aarnink et al. (1993), Turner et al. (1996), and Nyachoti et al. (2006). However, there was no study to investigate mechanisms to reduce odour gas emission. Therefore, further research is needed to understand the mechanism.

Wellock et al. (2008) reported that decreasing dietary protein supply might help to reduce enterotoxigenic Escherichia coli (ETEC) proliferation and faecal ETEC shedding. High protein in the diets encourages the proliferation of pathogenic bacteria by increasing microbial fermentation of undigested protein (Ball \& Aherne, 1987). However, the current experiment showed that pigs fed LCP tended $(P<0.055)$ to increase the count of $E$. coli in faeces compared with those that were fed the CON. In addition, when pigs were fed the LCP diet, Lactobacillus of beneficial bacteria was lower $(P<0.05)$ than in those fed the control diet (CON). The component of intestinal microbiota is known to have a great deal of volatility such as in temperature and use of probiotics (Penders et al., 2006). Therefore, further research is needed about a relationship between microflora and dietary nutrient density.

\section{Conclusion}

These results indicated that reducing dietary CP and ME could decrease BUN concentration in the 
blood and $\mathrm{NH}_{3}, \mathrm{H}_{2} \mathrm{~S}$, VFAs emissions in faeces without affecting growth performance in in weaned piglets.

Furthermore, these results indicated that reducing dietary $\mathrm{CP}$ and $\mathrm{ME}$ decreased BUN concentration in blood and $\mathrm{NH}_{3}, \mathrm{H}_{2} \mathrm{~S}$, VFAs emission in faeces. However, growth performance was not affected by reducing dietary $\mathrm{CP}$ and $\mathrm{ME}$.

\section{Acknowledgements}

This work was carried out with the support of the Cooperative Research Program for Agriculture Science \& Technology Development (Project No. PJ01261502), Rural Development Administration Republic of Korea.

\section{Authors' Contributions}

JHC and MHS oversaw the project design. WY supervised the course of the study. CHL, WGK, HJO oversaw sample collecting and participated in results and statistics. JHL and HBK wrote the manuscript and revised it.

\section{Conflict of Interest Declaration}

The authors declare that they have no conflict of interest.

\section{References}

Aarnink, A.J.A 1993. Factors affecting ammonium concentration in slurry from fattening pigs. In Proceedings of the Congress on Nitrogen Flow in Pig Production and Environmental Consequences (pp. 413-420). Pudoc.

Anderson, D.B., McCracken, V.J., Aminovi, R.I., Simpson, J.M., Mackie, R.I., Verstegen, M.W.A. \& Gaskins, H.R., 1999. Gut microbiology and growth-promoting antibiotics in swine. Pig. N. Inform. 20, 115-122.

AOAC. 2005. Official methods of analysis. 18th ed. Assoc. Anal. Chem., Arlington. VA.

Aumaitre, A., Peiniau, J. \& Madec, F., 1995. Digestive adaptation after weaning and nutritional consequences in the piglet. Pig. N. Inform. 16(3), 73N

Ball, R.O. \& Aherne, F.X., 1987. Influence of dietary nutrient density, level of feed intake and weaning age on young pigs. II. Apparent nutrient digestibility and incidence and severity of diarrhea. Can. J. Anim. Sci. 67(4), 1105-1115.

Benson, B.N., Calvert, C.C., Roura, E. \& Klasing, K.C., 1993. Dietary energy source and density modulate the expression of immunologic stress in chicks. J. Nutr. 123(10), 1714.

Bikker, P., Dirkzwager, A., Fledderus, J., Trevisi, P., le Huerou-Luron, I., Lalles, J.P. \& Awati, A., 2006. The effect of dietary protein and fermentable carbohydrates levels on growth performance and intestinal characteristics in newly weaned piglets. J. Anim. Sci. 84(12), 3337-3345.

Bolduan, V.G., Jung, H., Schnabel, E. \& Schneider, R., 1988. Recent advances in the nutrition of weaner piglets. Pig. N. Inform. 9(4), 381-385.

Bonnin, C., Laborie, A. \& Paillard, H., 1990. Odour nuisances created by sludge treatment: problems and solutions. Water. Sci. Technol. 22(12), 65-74.

Burnett, W.E., 1969. Air pollution from animal wastes. Determination of malodours by gas chromatographic and organoleptic techniques. Environ. Sci. Technol. 3(8), 744-749.

Dong, G., Zhou, A., Yang, F., Chen, K., Wang, K. \& Dao, D., 1996. Effect of dietary protein levels on the bacterial breakdown of protein in the large intestine, and diarrhoea in early weaned piglets. Chin. J. Anim. Vet. Sci. 27, 293302.

Dourmad, J.Y., Henry, Y., Bourdon, D., Quiniou, N. \& Guillou, D., 1993. Effect of growth potential and dietary protein input on growth performance, carcass characteristics and nitrogen output in growing-finishing pigs. EAAP (Netherlands).

Easter, R.A. \& Baker, D.H., 1980. Lysine and protein levels in corn-soybean meal diets for growing-finishing swine. J. Anim. Sci. 50(3), 467-471.

Figueroa, J.L., Lewis, A.J., Miller, P.S., Fischer, R.L., Gómez, R.S. \& Diedrichsen, R.M., 2002. Nitrogen metabolism and growth performance of gilts fed standard corn-soybean meal diets or low-crude protein, amino acid-supplemented diets. J. Anim. Sci. 80(11), 2911-2919.

Gaskins, H.R., 2001. Intestinal bacteria and their influence on swine growth. Swine. Nutr. 2, 585-608.

Hansen, J.A., Knabe, D.A. \& Burgoon, K.G., 1993. Amino acid supplementation of low-protein sorghum-soybean meal diets for 5-to 20-kilogram swine. J. Anim. Sci. 71(2), 452-458.

Hartung, J. \& Phillips, V.R., 1994. Control of gaseous emissions from livestock buildings and manure stores. J. Agr. Eng. Res. 57(3), 173-189.

Hastad, C.W., Tokach, M.D., Nelssen, J.L., Dritz, S.S., Goodband, R.D., De Rouchey, J.M., Jones, C.L. \& Frantz, N,Z., 2005. Effect of sorting and added fat level performance on grow-finish pigs reared in a commercial facility. J. Anim. Sci. 83 (Suppl. 2):80 (Abstract).

Högberg, A. \& Lindberg, J.E., 2004. Influence of cereal non-starch polysaccharides and enzyme supplementation on digestion site and gut environment in weaned piglets. Anim. Feed. Sci. Tech. 116(1), 113-128.

Hossain, M.M., Park, J.W. \& Kim, I.H., 2016. ס-Aminolevulinic acid, and lactulose supplements in weaned piglets diet: Effects on performance, fecal microbiota, and in-vitro noxious gas emissions. Livest. Sci. 183, 84-91.

Houdijk, J.G.M., Campbell, F.M., Fortomaris, P.D., Eckersall, P.D. \& Kyriazakis, I., 2007. Effects of sub-clinical postweaning colibacillosis and dietary protein on acute phase proteins in weaner pigs. Livest. Sci. 108(1), 182-185.

Just, A., 1982a. The net energy value of balanced diets for growing pigs. Livest. Prod. Sci. 8(6), 541-555.

Just, A., 1982b. The net energy value of crude (catabolized) protein for growth in pigs. Livest. Prod. Sci. 9(3), 349-360.

Kendall, D.C., 2000. Dietary manipulation of swine diets to reduce aerial ammonia, hydrogen sulfide, odour, and nutrient excretion; and evaluating the effects of pig genotype, sex, antibiotic use, and health management practices on 
lean growth rate, carcass characteristics, pork quality, and immune system variables. MS thesis, Purdue University, West Lafayette, IN.

Kephart, K.B. \& Sherritt, G.W., 1990. Performance and nutrient balance in growing swine fed low-protein diets supplemented with amino acids and potassium. J. Anim. Sci. 68(7), 1999-2008.

Kerr, B.J. \& Easter, R.A., 1995. Effect of feeding reduced protein, amino acid-supplemented diets on nitrogen and energy balance in grower pigs. J. Anim. Sci. 73(10), 3000-3008.

Kerr, B.J., McKeith, F.K. \& Easter, R.A., 1995. Effect on performance and carcass characteristics of nursery to finisher pigs fed reduced crude protein, amino acid-supplemented diets. J. Anim. Sci. 73(2), 433-440

Lee, J.H., Kim, J.H., Kim, J.D., Kim, S.W. \& Han, I.K., 2001. Effects of low crude protein diets supplemented with synthetic amino acids on performance, nutrient utilization and carcass characteristics in finishing pigs reared using a phase feeding regimen. Asian Austral. J Anim. Sci.14(5), 655-667.

Miner, J.R., 1977. Characterization of odours and other volatile emissions. Agr. Environ. 3(2-3), 129-137.

Noblet, J., Henry, Y. \& Dubois, S., 1987. Effect of protein and lysine levels in the diet on body gain composition and energy utilization in growing pigs. J. Anim. Sci. 65(3), 717-726.

NRC. 1998. Nutrient requirements of swine. 10th rev. ed. Natl. Acad. Press, Washington, DC. Pp 110-142.

Nyachoti, C.M., Omogbenigun, F.O., Rademacher, M. \& Blank, G., 2006. Performance responses and indicators of gastrointestinal health in early-weaned pigs fed low-protein amino acid-supplemented diets. Journal of Animal Science, 84(1), 125-134.Penders, J., Thijs, C., Vink, C., Stelma, F.F., Snijders, B., Kummeling, I. \& Stobberingh, E.E., 2006. Factors influencing the composition of the intestinal microbiota in early infancy. Pediatrics, 118(2), 511-521.

Pluske, J.R., Pethick, D.W., Hopwood, D.E. \& Hampson, D.J., 2002. Nutritional influences on some major enteric bacterial diseases of pig. Nutr. Res. Rev. 15(02), 333-371.

Ritter, W.F., 1989. Odour control of livestock wastes: State of the art in North America. J. Agr. Eng. Res. 42(1), 51-62.

Russell, L.E., Cromwell, G.L. \& Stahly, T.S., 1983. Tryptophan, threonine, isoleucine and methionine supplementation of a $12 \%$ protein, lysine-supplemented, corn-soybean meal diet for growing pigs. J. Anim. Sci. 56(5), 1115-1123.

SAS Institute, 2008. SAS user's guide, Statistical Analysis System Inst. Inc Cary NC.

Shriver, J.A., Carter, S.D., Sutton, A.L., Richert, B.T., Senne, B.W. \& Pettey, L.A., 2003. Effects of adding fiber sources to reduced-crude protein, amino acid-supplemented diets on nitrogen excretion, growth performance, and carcass traits of finishing pigs. J. Anim. Sci. 81(2), 492-502.

Smith II, J.W., Tokach, M.D., Nelssen, J.L. \& Goodband, R.D., 1999. Effects of lysine : calorie ratio on growth performance of 10- to 25-kilogram pigs. J. Anim. Sci. 77: 3000-3006.

Song, G.L., Li, D.F., Piao, X.S., Chi, F. \& Yang, W.J., 2003. Apparent ileal digestibility of amino acids and the digestible and metabolizable energy content of high-oil corn varieties and its effects on growth performance of pigs. Arch. Anim. Nutr. 57(4), 297-306.

Stahly, T.S., 1984. Use of fats in diets for growing pig. pp: 313-331. Fats in animal nutrition. Anchor Brendon, Essex, Great Britain.

Tokach, M.D., Pettigrew, J.E., Johnston, L.J., Overland, M., Rust, J.W. \& Cornelius, S.G., 1995. Effect of adding fat and (or) milk products to the weanling pig diet on performance in the nursery and subsequent grow-finish stages. J. Anim. Sci. 73(11), 3358-3368.

Turner, L.W., Cromwell, G.L., Bridges, T.C., Carter, S. \& Gates, R.S., 1996. Ammonia (NH 3) emission from swine waste as influenced by diet manipulation. In Proceedings of the First International Conference on Air Pollution from Agricultural Operations (pp. 5-9).

Wahlstrom, R.C. \& Libal, G.W., 1974. Gain, feed efficiency and carcass characteristics of swine fed supplemental lysine and methionine in corn-soybean meal diets during the growing and finishing periods. J. Anim. Sci. 38(6), 12611266.

Wellock, I.J., Fortomaris, P.D., Houdijk, J.G.M. \& Kyriazakis, I., 2008. Effects of dietary protein supply, weaning age and experimental enterotoxigenic Escherichia coli infection on newly weaned pigs: health.

Whang, K.Y., Kim, S.W., Donovan, S.M., McKeith, F.K. \& Easter, R.A., 2003. Effects of protein deprivation on subsequent growth performance, gain of body components, and protein requirements in growing pigs. J. Anim. Sci. 81(3), 705-716.

Whittemore, C.T., Tullis, J.B. \& Hastie, S.W., 1978. Efficiency of use of nitrogen from dried microbial cells after a period of $\mathrm{N}$ deprivation in growing pigs. Brit. J. Nutr. 39(01), 193-200.

Williams, C.H., David, D.J., \& lismaa, O., 1962. The determination of chromic oxide in faeces samples by atomic absorption spectrophotometry. J. Agr. Sci. 59(03), 381-385

Yan, L., Wang, J.P., Kim, H.J., Meng, Q.W., Ao, X., Hong, S.M. \& Kim, I.H., 2010. Influence of essential oil supplementation and diets with different nutrient densities on growth performance, nutrient digestibility, blood characteristics, meat quality and fecal noxious gas content in grower-finisher pigs. Livest. Sci. 128(1), 115-122.

Zahn, J.A., Hatfield, J.L., Do, Y.S., DiSpirito, A.A., Laird, D.A. \& Pfeiffer, R.L., 1997. Characterization of volatile organic emissions and wastes from a swine production facility. J. Environ. Qual. 26(6), 1687-1696.

Zhao, P.Y., Wang, J.P. \& Kim, I.H., 2013. Evaluation of dietary fructan supplementation on growth performance, nutrient digestibility, meat quality, fecal microbial flora, and fecal noxious gas emission in finishing pigs. J. Anim. Sci. 91(11), 5280-5286. 